\title{
MEXICAN IMMIGRATION TO SOUTHERN CALIFORNIA: ISSUES OF JOB COMPETITION AND WORKER MOBILITY
}

\author{
Donald M. Manson, Thomas J. Espenshade, and Thomas Muller*
}

\section{Introduction}

Currently the United States is experiencing one of the most massive waves of immigration in its history. The problem has grown so large that it has raised concerns among citizens that major action is necessary to protect American workers and has prompted President Reagan to declare that "we've lost control of our borders." Despite the rising concern, however, we remind ourselves that this is a country of immigrants, and much of our development has come as a result of major waves of immigration lasting over long periods.

Now, as often in the past, the influx from abroad has raised fears of insecurity among native workers, especially blue-collar workers, about newly arrived immigrants taking their jobs. The fear is that employers will exploit the eagerness of immigrants to work at nearly any job under poor conditions and for wages below what native workers will accept. Thus it is believed that American workers will be unable to compete effectively in the job market, leaving them unemployed and perhaps unemployable.

These fears of workers were apparent in a survey conducted for The Urban Institute in June 1983 by the Field Research Corporation. California residents were asked about their perceptions of the impact of immigration on the region. Nearly half (48.2 percent) of the respondents believed that illegal immigrants take jobs away from citizens and contribute to unemployment. Among blacks in the survey, 58 percent believed that jobs were threatened.

Although plausible, this argument makes sense only if immigrant workers in fact

*The Urban Institute, Washington, D.C. Research for this article was supported by a grant from The Weingart Foundation. Charles Calhoun devised and performed the statistical tests for the CPS data, and Tracy Ann Goodis assisted in the calculations. The capable technical assistance of Marianna Diggs and Bobbie Mathis is also gratefully acknowledged. Opinions expressed here are those of the authors and do not necessarily reflect the viows of The Urban Institute or any of its sponsors. compete directly with resident workers for the same jobs, and if immigrants do not create a demand for new goods and services whose production would cause a spinoff need for native workers. Moreover, whether immigrants displace native-born workers depends on several additional factors, such as whether or not there is an imbalance in the demand for the type of labor immigrants provide and whether low-and high-skill labor are complements or substitutes.

Excess demand can arise if one views labor markets as segmented into primary and secondary sectors (Piore, 1979). In this context, if secondary jobs are considered "undesirable" by native workers, then the demand for immigrant labor is initiated by employers seeking to fill such undesirable jobs. The extent to which substitution exists among various types of workers is an empirical question, one that numerous researchers have attempted to estimate. In general, these studies have reached inconclusive results (Hamermesh and Grant, 1979; Johnson, 1980).

The political response at the national level to porous borders and the threat of job competition has been the introduction of the SimpsonMazzoli immigration reform bill. This legislation directly addresses the concerns of American workers through provisions making it illegal for employers to hire immigrants without proper documentation of their legal status. With the imposing of penalties on employers who violate the law, it is reasoned that few jobs will be available for persons here illegally and that a lack of job opportunities will discourage further illegal immigration into the country. Because of this, the pending legislation has been characterized by some as a "jobs bill."

Few, if any, areas in the United States have been more sharply affected by immigration than California. Currently, it is the intended state of residence for over one-quarter of all legal immigrants (Immigration and Naturalization Service, 1981). Throughout the 1970s and continuing to the present, this region has experienced intense and accelerating immigration, both legal and illegal. As part of our ongoing research on the consequences of Mexican immigration to Southern California, we have 
examined some of the propositions about labor market impacts that led to the introduction of legislation for immigration reform (Muller, 1984). If a massive influx of low-wage low-skill workers produces any impact on the availability of jobs, this effect should be apparent in Southern Californian labor markets with large concentrations of immigrant workers. To focus the inquiry, we examine labor market changes in the low-wage manufacturing sector in the Los Angeles metropolitan area where Mexican workers have a major presence (North and Houston, 1976). Additionally, since blacks may face greater direct job competition from Mexican immigrants than do other workers, we also examine this labor market group specifically as well as the labor market as a whole.

Concern over the immigration of Mexicans stems not only from their numbers, but also from their largely undocumented (illegal) status, low education and skill levels, and poor English-speaking ability-characteristics that would tend to place them in direct competition with native workers for jobs at the bottom of the wage and skill hierarchy. Contrary to the expectations of survey respondents, however, our analysis finds no evidence of an immigration-induced increase in unemployment in the Los Angeles metropolitan area, even with its concentration of undocumented Mexican immigrants. But there are indications that this immigration may have altered the pattern of internal migration to the region. The evidence suggests that there has been a decline in the rate of low-wage workers migrating to California from other parts of the country during a time when the flow of immigrants from Mexico increased. More generally, the rate of overall internal migration to the state has dropped while the rate of out-migration has risen steadily.

\section{A Profile of Immigrants}

Our analysis focuses on Mexican immigrants in Los Angeles. More than two-thirds of all immigrants in California arriving since 1970 have tended to settle in the southern part of the state, and in Los Angeles in particular. However, contrary to what is generally believed, Mexicans do not form a majority of all immigrants to California, nor are they a majority in Los Angeles, although they do constitute the largest single nationality among immigrants.

Of the more than 15 percent of residents in California in 1980 who were foreign born, only about one-third were Mexican while more than half were non-Hispanic. Among Mexican immigrants, Table 1 shows that almost two-thirds of those in Los Angeles have come since 1970, and more than half of those arrived in the second half of the decade. Among the foreign born living in Los Angeles, Mexicans account for less than half of those who immigrated between 1970 and 1980. For non-Hispanic immigrants as a group, the majority arrived before 1970 and are from Europe, although the bulk of the most recent (since 1970) non-Hispanic arrivals have come from Asia.

As a policy issue, the greatest concern about immigration is over those who are here illegally. Not only are illegal immigrants perhaps the most likely to have an impact on the lowwage labor market, but their numbers are uncontrolled and largely unknown. Additionally, as preparation for immigration reform, it is important to know the number of immigrants who are here illegally to indicate how many

Table 1

Immigration to California by Country of Origin and Period of Entry to the U.S. (numbers in thousands)

\begin{tabular}{|c|c|c|c|c|c|c|c|c|c|c|c|c|}
\hline \multirow{3}{*}{$\begin{array}{l}\text { Period of } \\
\text { Entry }\end{array}$} & \multicolumn{6}{|c|}{ California } & \multicolumn{6}{|c|}{ Los Angeles } \\
\hline & \multicolumn{2}{|c|}{ Total } & \multicolumn{2}{|c|}{ Mexican } & \multicolumn{2}{|c|}{ Other } & \multicolumn{2}{|c|}{ Total } & \multicolumn{2}{|c|}{ Mexican } & \multicolumn{2}{|c|}{ Other } \\
\hline & Number & Percent & Number & Percent & Number & Percent & Number & Percent & Number & Percent & Number & Percent \\
\hline Total & 3,580 & 100.0 & 1,278 & 100.0 & 2,302 & 100.0 & 1,665 & 100.0 & 698 & 100.0 & 967 & 100.0 \\
\hline $1975-1980$ & 1,124 & 31.4 & 437 & 34.2 & 687 & 29.8 & 579 & 34.8 & 255 & 36.5 & 324 & 33.5 \\
\hline $1970-1974$ & 681 & 19.0 & 336 & 26.3 & 345 & 15.0 & 370 & 22.2 & 201 & 28.8 & 168 & 17.4 \\
\hline $1965-1969$ & 457 & 12.8 & 174 & 13.6 & 283 & 12.3 & 216 & 13.0 & 96 & 13.8 & 120 & 12.4 \\
\hline $1960-1964$ & 358 & 10.0 & 122 & 9.6 & 237 & 10.3 & 147 & 8.8 & 56 & 8.0 & 91 & 9.4 \\
\hline Before 1960 & 959 & 26.8 & 208 & 16.3 & 751 & 32.6 & 353 & 21.2 & 90 & 12.9 & 263 & 27.2 \\
\hline
\end{tabular}

Source: U.S. Bureau of the Census, 1980 Census of Population, Vol. 1, Characteristics of the Population, Chapter D: Detailed Population Characteristics, Part 6, California, PC80-1-D6, November 1983. 
eligible immigrants may seek amnesty under proposed immigration reform legislation. Despite this importance, it is difficult to estimate the number of immigrants who are undocumented. No direct data are available, and estimates must be based on census enumerations and Immigration and Naturalization Service data that have only partial coverage.

Estimates have recently been made by Passel and Woodrow (1984) of the number of undocumented immigrants enumerated in the 1980 Census, by individual states and for the U.S. as a whole. According to these estimates, Mexicans historically have had a much higher rate of illegal entry than immigrants from other countries, and the share of Mexicans here illegally is substantially higher among those who have entered most recently. For California, these estimates indicate that almost threefourths (73 percent) of Mexican immigrants entering between 1975 and 1980 are undocumented, while the undocumented share is less than half ( 45 percent) for those who entered prior to 1975. By comparison, immigrants from other countries have much lower rates of illegal entry, undoubtedly due in large part to the greater difficulty of entry from countries not having a common border with the U.S. Within this group, about one-fourth (24 percent) of the immigrants who entered between 1975 and 1980 are estimated to be here without proper documentation. Among those who came here earlier, about one-fifth are here illegally.

In addition to their large numbers, Mexican immigrants also pose a potential threat to lowskill native workers because of their poor educational attainment. Among Mexican immigrants enumerated in the 1980 census, nearly three-fourths of those in California had not completed their education through the eighth grade, and scarcely two percent had a college education or better. In Los Angeles County, Mexican immigrants had slightly better levels of educational attainment than those in the state as a whole, as shown by Table 2. By comparison, among other Hispanic immigrants in the state, only about one in three had not completed an eighth grade education, while one out of eight had completed four or more years of college. Non-Hispanic immigrants-mostly Europeans and Asians-had much higher levels of education, with only about one-fifth of this group having no high school education.

The 1980 census data also indicate that the English-speaking ability of recent Mexican immigrants is generally poor. Among those who arrived between 1970 and 1980,32 percent responded to census questions that they did not speak English well, and another 29 percent said that they did not speak it at all. Those who were 18 years and older, and potentially in the labor force, had even less facility with English. About 35 percent did not speak English well, and a similar amount spoke none at all. Non-Mexican immigrants who entered in the same period had a substantially better command of English-only 20 percent said they did not speak English well, while less than 10 percent said they did not speak any English.

Not surprisingly, with their low levels of education and poor English-speaking ability, Mexican immigrants primarily hold jobs at the lowest level of the job hierarchy. As shown in Table 3, nearly three-fourths of all Mexicans immigrating 10 the U.S. between 1970 and 1980 held jobs with an occupation classified as semi-skilled or unskilled, while only about one in eight had a job classified as white-collar. The situation of native-born blacks is between that of Spanish-origin persons and non-Hispanic whites and Asians. Perhaps a third of all blacks in Los Angeles have low-skill jobs that

Table 2

Educational Attainment of Mexican Immigrants in Los Angeles County, $1980^{\mathrm{a}}$

\begin{tabular}{crrr}
\hline Years of School & Number & Percent & Cumulative Percent \\
\hline Total & 357,220 & 100.0 & - \\
$0-4$ & 95,500 & 26.7 & 26.7 \\
$5-8$ & 142,520 & 39.9 & 66.6 \\
$9-12$ & 88,300 & 24.7 & 91.3 \\
$13-16$ & 25,760 & 7.2 & 98.5 \\
$17+$ & 5,140 & 1.4 & 100.0 \\
\hline
\end{tabular}

Includes only migrants 26 years old and older.

Source: Tabulations by The Urban Institute of the 1980 Census Public Use Microdata Sample. 
Table 3

Occupational Distribution by Ethnic Group in Los Angeles County, 1980

\begin{tabular}{lccrrr}
\hline \hline Occupational Category & $\begin{array}{l}\text { Mexican } \\
\text { Immigrants }\end{array}$ & $\begin{array}{l}\text { Mexican } \\
\text { Americans }\end{array}$ & Blacks & Asians & $\begin{array}{c}\text { Non-Hispanic } \\
\text { Whites }\end{array}$ \\
\hline & \multicolumn{7}{c}{ Percentage Distribution } \\
\cline { 2 - 6 } All Occupations & 100.0 & 100.0 & 100.0 & 100.0 & 100.0 \\
Professional, Managerial, Technical & 3.0 & 12.8 & 21.4 & 34.3 & 35.3 \\
Other White Collar & 8.6 & 30.1 & 33.0 & 30.6 & 33.0 \\
Skilled Blue Collar & 15.0 & 13.7 & 9.3 & 9.2 & 11.8 \\
Other & 73.4 & 43.4 & 36.3 & 25.9 & 19.8 \\
\hline \hline
\end{tabular}

a Mexican immigrants who arrived between 1970 and 1980.

Source: U.S. Bureau of the Census, 1980 Census of Population, Vol. 1, Characteristics of the Population, Chapter C: General Social and Economic Characteristics, Part 6, California, PC80-1-C6, July 1983; and tabulations by The Urban Institute of the 1980 Census Public Use Microdata Sample.

potentially could be taken by low-skill immigrants. Among native-born whites, only about a fifth hold jobs classified as unskilled.

In short, Mexican immigrants in Los Angeles arrive with very low levels of education, and the vast majority hold jobs at the lowest skill level. By both measures of comparison, their status is the lowest among major immigrant ethnic groups, and lower by an even larger margin than native-born Californians.

\section{Employment and Unemployment}

The 1970s were a period of rapid job expansion in Southern California. Two-thirds of this growth was in white-collar jobs, which grew at a rate about one-third above the national average. Although fewer blue-collar jobs were added, the rate of their increase was about twice the national rate, with the expansion attributable primarily to employment growth in the manufacturing sector. In Los Angeles the pace of this increase was even stronger, with manufacturing jobs increasing by 14 percent, compared with only 5 percent national growth (U.S. Bureau of Labor Statistics). Of all jobs added in Los Angeles County during the 1970 s, about one-third were taken by Mexican immigrants. For all service and skilled bluecollar jobs, this group accounted for about half of the number added during this period.

By a wide margin manufacturing employs the greatest number of Mexican immigrants living in Los Angeles. Over two hundred thousand work in this sector, accounting for half the employment of all Los Angeles Mexican immigrants. Mexican immigrants also have a significant presence among all county residents who are employed in manufacturing - they comprise
23 percent of all residents in manufacturing and 29 percent of the total in non-durable manufacturing. In general, the occupational skill requirements of the jobs held by this group are low, with nearly three-fourths of the manufacturing jobs held by Mexican immigrants classified as low skill. After manufacturing, the service and retail trade sectors are the next largest employers, accounting for one out of six and one out of seven Mexican immigrant workers, respectively.

Given this conspicuous immigrant presence in the Los Angeles manufactoring sector in 1980 , it is of interest to ask what effect, if any, this had on the employment of non-immigrant groups in the Los Angeles work force. The answer is shown in Table 4. When taken as a whole, net manufacturing employment increased by 113 thousand during the decade of the 1970s. However, since immigrants arriving after 1970 took 168 thousand manufacturing jobs, there must have been a net decline of 55 thousand jobs among other workers during the decade. Importantly, this does not necessarily imply that the difference of 55 thousand were workers displaced by immigrants. Given the high turnover rate in the manufacturing sector, such a change may reflect native-born workers voluntarily leaving low-wage, low-skill jobs in the manufacturing sector for other employment.

The number of jobs taken by Mexican immigrants in all of the non-manufacturing sectors was only about equal to the total of manufacturing jobs. Within this group, one of the most dramatic changes occurred in personal services where all immigrants combined took 24.4 thousand jobs, of which Mexicans claimed 10.3 thousand, at a time when the sector ac- 
tually lost 7.4 thousand jobs.

The question remains as to whether immigration hurt the job prospects of particular subgroups within the labor force, and especially those of blacks, since they may be the most likely to hold jobs for which immigrants might compete. A regression analysis was performed to estimate the coefficients of a simple labor market model to test whether concentrations of Hispanics in the labor market increase the unemployment rate of blacks. Unemployment rates for blacks were estimated as a function of the share of Hispanics (used as a proxy for immigrant share) in the population and other factors affecting unemployment including the rate of population growth in an area, the education level of the black work force, and general economic conditions in the area. One would expect rates of local area population growth to be inversely related to unemploy- ment rates; population growth stimulates demand creating new jobs, and workers are apt to migrate to areas with low unemployment. Higher eductation enables blacks (and others) to be more competitive for jobs in the economy. Finally, black unemployment should be affected by general economic conditions in the same way as white unemployment. In addition, when examining black labor force activity, it is important to control for the concentration of cyclically sensitive durable goods manufacturing and construction, as these industries experience high rates of unemployment during economic downturns. Since blacks are overrepresented in blue-collar manufacturing, their unemployment rates during periods of relatively slow growth or decline can be expected to be above average in areas with heavy concentrations of manufacturing industry.

Table 4

Recent Immigrant Share of Los Angeles Net Employment Growth, Selected Industries: 1970-1980 (numbers in thousands)

\begin{tabular}{|c|c|c|c|c|}
\hline \multirow[b]{2}{*}{ Sector } & \multirow{2}{*}{$\begin{array}{c}\text { Total Employment Growth } \\
1970-1980 \\
\text { (1) }\end{array}$} & \multicolumn{2}{|c|}{$\begin{array}{l}\text { Employment of Immigrants } \\
\text { Arriving Between } 1970-1980\end{array}$} & \multirow{2}{*}{$\begin{array}{l}\text { Net Replacement } \\
\begin{array}{c}(1)-[(2)+(3)] \\
(4)\end{array}\end{array}$} \\
\hline & & $\begin{array}{l}\text { Mexicans } \\
\quad(2)\end{array}$ & $\begin{array}{l}\text { All Others } \\
\text { (3) }\end{array}$ & \\
\hline Manufacturing & 113.2 & 105.8 & 62.5 & -55.1 \\
\hline Eating \& drinking & 52.1 & 15.3 & 13.7 & 23.1 \\
\hline Other retail & 32.1 & 15.7 & 27.1 & -10.7 \\
\hline Personal services & -7.4 & 10.3 & 14.1 & -31.8 \\
\hline Business services & 64.4 & 9.9 & 13.2 & 41.3 \\
\hline Other services & 213.0 & 15.9 & 45.8 & 151.3 \\
\hline All other & 177.8 & 37.0 & $\mathbf{5 7 . 3}$ & 83.5 \\
\hline Total & 645.2 & 209.9 & 233.7 & 201.6 \\
\hline
\end{tabular}

Source: Tabulations by The Urban Institute of the 1980 Census Public Use Microdata Sample; and U.S. Bureau of the Census, 1980 Census of Population, Vol. 1, Characteristics of the Population, Chapter C: General Social and Economic Characteristics, Part 6, California, PC80-1-C6, July 1983; U.S. Bureau of the Census, 1980 Census of Population, Vol. 1, Characteristics of the Population, Chapter D: Detailed Population Characteristics, Part 6, California, PC80-1-D6, November 1983. 
The labor market equation for the rate of black unemployment was estimated for 247 metropolitan areas using 1980 census data after dropping from a total of 318 metropolitan areas those places having fewer than 3000 black residents. Areas with few blacks could introduce distortions into the results. For example, a military installation in a small metropolitan area might account for a large share of black jobs, and all these workers would by definition be employed.

The estimated labor market equation was:

UBLK = $\mathrm{f}$ (PCTHISP, GROWTH, PCTCNDUR, PCTHSBLK, UWHT, u)

where, for each metropolitan area:

UBLK = rate of unemployment for blacks,

PCTHISP = percent of Hispanics in the population,

GROWTH = rate of population growth between 1970 and 1980 ,

PCTCNDUR $=$ percent of income earned in construction and durable goods manufacturing,

PCTHSBLK $=$ percent of blacks 25 years old and over with at least a high school education,

UWHT = rate of unemployment for whites (as a control for local economic factors affecting all workers), and

$\mathbf{u}$ $=$ random error term.

The results of the regression analysis are shown in Table 5 and point to a rejection of the hyopthesis that an increase in the proportion of Hispanics in the local labor market increases black unemployment rates. There is no statistically significant relationship between black rates of unemployment and the concentration of Hispanics in the labor force. Signs of the other coefficients are as one would expect. Thus, after accounting for general labor market conditions that affect blacks and whites alike, most of the variation in black unemployment among areas can be attributed to differences in black educational attainment, in the rate of population growth, and in the degree of durable goods manufacturing in the metropolitan area.

Data in Table 6 from Southern California labor markets confirm these findings. Despite mass immigration to Southern California between 1970 and 1982 , unemployment rates there rose less rapidly for blacks and for all persons than in the remainder of the nation. It is possible, of course, that these unemployment statistics disguise a situation where workers who are unemployed for long periods leave the labor force as they become discouraged about the prospects of finding acceptable employment. However, this does not appear to be the case, as shown by the labor force participation rates in Table 6. For both blacks and the general population, labor force participation rates in the Los Angeles metropolitan area exceeded national averages. In sum, it would appear that recent Mexican immigration to Southern California has not resulted in any significant adverse consequences for unemployment rates.

Even though our regression analysis did not find that Mexican immigrants (as indicated by Hispanic concentration) increase black unemployment, such an analysis does not provide an explanation for this finding. An examination of black employment changes during the $1970 \mathrm{~s}$ in Los Angeles County provides at least a partial

Table 5

Coefficient Estimates for Black Unemployment Rates

\begin{tabular}{lcrr}
\hline & $\begin{array}{c}\text { Estimated } \\
\text { Coefficient }\end{array}$ & t-statistic & Beta \\
\hline Constant & 0.1298 & 4.49 & 0 \\
PCTHISP & -0.0087 & -0.48 & -0.0167 \\
GROWTH & -0.0893 & -3.75 & -0.1370 \\
PCTCNDUR & 0.0725 & 3.37 & 0.1222 \\
PCTHSBLK & -0.0346 & -2.47 & -0.0830 \\
UWHT & 1.6394 & 21.10 & 0.7538 \\
R-squared & 0.75 & & \\
Number of Observations & 247 & & \\
\end{tabular}

Source: Regression estimated from data from the 1980 Census of Population. 
Table 6

Unemployment and Labor Force Participation Rates for the Los Angeles Standard Consolidated Metropolitan Area, California, and the United States: 1970, 1980, and 1982

\begin{tabular}{|c|c|c|c|c|c|c|}
\hline \multirow[b]{2}{*}{ Age Group } & \multicolumn{3}{|c|}{ All Parcons. } & \multicolumn{3}{|c|}{ Blacks } \\
\hline & 1870 & 1880 & 1882 & 1970 & $1080^{n}$ & 1982 \\
\hline Ages 20 and over & \multicolumn{6}{|c|}{ Unemployment rates } \\
\hline Los Angeles SCMA $^{e}$ & 5.5 & 5.2 & $8.5^{b}$ & $8.9^{c}$ & 8.8 & $11.3^{b}$ \\
\hline California & 5.7 & 5.9 & 8.9 & 9.2 & 9.8 & 14.6 \\
\hline United States & 3.8 & 5.9 & 8.6 & 6.0 & 11.2 & 16.6 \\
\hline \multicolumn{7}{|l|}{ Ages 16-19 } \\
\hline Los Angeles SCMA ${ }^{e}$ & 13.6 & 13.4 & $23.9^{b}$ & $26.2^{c}$ & 30.5 & $35.4^{b}$ \\
\hline California & 15.1 & 14.4 & 23.4 & 27.9 & 30.6 & 39.7 \\
\hline United States & 11.2 & 15.2 & 23.2 & 19.4 & 35.8 & 48.1 \\
\hline Ages 20 and over & \multicolumn{6}{|c|}{ Labor force participation rates ${ }^{d}$} \\
\hline Los Angeles SCMA & 60.9 & 65.8 & $66.9^{b}$ & $63.1^{c}$ & 66.2 & $66.6^{\mathrm{b}}$ \\
\hline California & 59.0 & 64.2 & 67.2 & 61.1 & 65.8 & 66.5 \\
\hline United States & 58.8 & 63.7 & 65.0 & 60.7 & 64.3 & 64.3 \\
\hline Ages 16-19 & & & & & & \\
\hline Los Angeles SCMA & 41.8 & 50.0 & $51.2^{b}$ & $29.3^{c}$ & 46.8 & $39.0^{b}$ \\
\hline California & 38.9 & 49.9 & 54.1 & 28.5 & 47.3 & 38.4 \\
\hline United States & 39.2 & 51.0 & 54.1 & 29.1 & 39.5 & 36.6 \\
\hline \multicolumn{7}{|c|}{$\begin{array}{l}\text { Includes all nonwhite persons. } \\
\text { bExcludes Ventura County. } \\
\text { cExcludes Orange and Ventura Counties. } \\
\text { dLabor force participation rates for } 1982 \text { and for blacks in } 1980 \text { are based on the civilian noninstitutional } \\
\text { population instead of total population. } \\
\text { oThe Los Angeles Standard Consolidated Metropolitan Area consists of Los Angeles, Orange, Riverside, San } \\
\text { Bernardino, and Ventura Counties. } \\
\text { Sources: U.S. Bureau of the Census, } 1970 \text { and } 1980 \text { Censuses of Population, Characteristics of the Population: }\end{array}$} \\
\hline $\begin{array}{l}\text { Sources: U.S. Bureau } \\
\text { General Soc } \\
\text { and Earming }\end{array}$ & Censu & & Censuses o & tion, $C h$ & stics of & loylation: \\
\hline
\end{tabular}

answer. Net black employment during the decade increased by 105 thousand workers, with 96 thousand of this total in white-collar occupations. Recent immigrants from Mexico held only 16 thousand white-collar jobs. The number of blacks holding such jobs as low-skill operators and laborers actually declined, a pattern also observed among other non-immigrant groups.

\section{Geographic Mobility of the Labor Force}

The relationship between internal migration and immigration to the United States from 1870 to 1920 has been examined by Eldridge and Thomas (1964). During this 50-year period, net internal migration rates for native-born whites were inversely related to the rate of white immigration in all parts of the country except the West. This region continued to attract both internal migrants and immigrants. Similar forces may be at work in California today. The large inflow of foreign-born workers to California during the 1970 s may have reduced the internal flow of persons to the state and/or accelerated the outflow from California to other parts of the country.

Since the time of the gold rush, California's population growth has been fueled by immigrants from abroad and by migrants from east of the Rocky Mountains (Hernandez, 1971; Morrison, 1971). During the late 1950s, as shown in Table 7, 1.9 million internal migrants moved to California, whereas only 0.8 million left, for a net gain of 1.1 million. Net migration to California slowed considerably in the late 1960 s to 370,000 and had practically disappeared by the late $1970 \mathrm{~s}$. It is important to point out that this decline in net migration has been attributable largely to an increase in the number of people leaving California and not to a reduction in the number of in-migrants. The rate of in-migration, however, has declined 
Table 7

Migration Within the United States to and from California: $1935-40$ to $1975-80^{\mathrm{a}}$

\begin{tabular}{lcrrrrr}
\hline \hline \multirow{2}{*}{ Period } & \multicolumn{2}{c}{ In-migrants } & & \multicolumn{2}{c}{ Out-migrants } & \multirow{2}{*}{ Net migrants } \\
\cline { 2 - 5 } & Number & Rate $^{c}$ & & Number & Rate $^{c}$ & \\
\hline $1975-1980^{\mathrm{b}}$ & $1,877,289$ & 9.25 & & $1,782,831$ & 75.33 & 94,458 \\
$1965-1970$ & $1,783,534$ & 9.73 & & $1,413,542$ & 70.78 & 369,992 \\
$1955-1960$ & $1,938,130$ & 11.85 & & 815,926 & 51.91 & $1,122,204$ \\
$1935-1940$ & 876,829 & 7.03 & & 211,963 & 30.69 & 664,866 \\
\hline
\end{tabular}

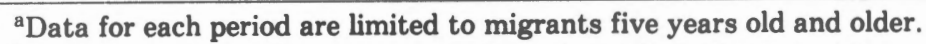

'Nonresponses to the question asking place of residence in 1975 were allocated in 1980 , but not in previous censuses.

${ }^{\mathrm{c}}$ Migration rates (per thousand population) based on decennial census at end of period. Out-migration rate based on California population; in-migration rate based on U.S. population minus California.

Sources: 1975-80: U.S. Bureau of the Census, State of Residence in 1975 by State of Residence in 1980, Supplementary Report, 1980 Census of Population, PC80-S1-9, March 1983, Washington, D.C., U.S. Government Printing Office; 1965-70: U.S. Bureau of the Census, Mobility for States and the Nation, Census of Population: 1970, Subject Reports, Final Report PC(2)-2B, Washington, D.C., U.S. Government Printing Office; 1955-60 and 1935-40: data supplied by Larry Long, Center for Demographic Studies, U.S. Bureau of the Census. Data from the 1950 Census of Population are omitted since they refer to place of residence one year prior to the census.

while the rate of out-migration has increased sharply.

The virtual cessation of net internal migration to California is inherently noteworthy because it contradicts the popular impression that internal migrants continue to be an important factor contributing to California's population growth. But it is also significant for two other reasons. First, the deceleration in net internal movement to California has occurred at the same time that immigration to California is accelerating. We showed earlier, for instance, that the distribution of foreign-born persons in California in 1980, tabulated by year of entry to the United States, shows a sharp upturn for more recent entrants. Second, the decline for California in net internal migration between 1965-1970 and 1975-1980 contrasts with the increase in the West region as a whole. Prior to 1975-1980, patterns of net internal migration to California parallelled those to the West in general. For the West census region, net internal migration was 590,000 between 1935 and 1940; it rose to $1,426,000$ for the period 1955-1960; and then fell to 695,000 between 1965 and 1970 . However, from 1975 to 1980 , net migration to the West jumped to $1,178,000$. This sharp rise not only contradicted the trend for California, but it was accompanied by approximately 800,000 more persons migrating to the West between 1975 and 1980 than had been the case a decade earlier. ${ }^{1}$

A closer examination of the number and characteristics of persons moving to and from California within the U.S. over the period between 1970 and 1983 is made possible by special tabulations from the March Current Population Surveys.\& Data from the Current Population Survey (CPS) are, however, not entirely comparable to decennial census data, because the CPS universe is limited to the civilian noninstitutional population. In addition, CPS data are derived from a sample survey of the population and not from a complete enumeration. Therefore all CPS-based estimates are subject to sampling error. In Tables 8,9 , and 10 , the statistical significance of the net migration numbers is gauged using a Pearson Chi-square test, where the null hypothesis being tested is that net migration is zero. P-values are reported so the reader may assess the results for any predetermined level of significance.

The CPS data in Table 8 show that net migration to California slowed further and possibly even reversed between the early and late 1970s. Since 1980 the amount of net internal migration to California has been negligible (just 11,000 over a three-year period). Within 
Table 8

Migration Within the United States to and from California, by Sex, Race, and Spanish Origin: 1970-1983

(numbers in thousands)

\begin{tabular}{|c|c|c|c|c|c|c|}
\hline \multirow[t]{2}{*}{ Period and Item } & \multicolumn{2}{|c|}{ In-migrants ${ }^{c}$} & \multicolumn{2}{|c|}{ Out-migrants ${ }^{c}$} & \multirow{2}{*}{$\begin{array}{c}\text { Net } \\
\text { migrantge }\end{array}$} & \multirow{2}{*}{$\begin{array}{c}\text { p- } \\
\text { valued }\end{array}$} \\
\hline & Number & Percent & Number & Pricont & & \\
\hline \multicolumn{7}{|l|}{$1980-1983^{a}$} \\
\hline Total & 1,721 & 100.0 & 1,710 & 100.0 & 11 & .8510 \\
\hline Male & 837 & 48.6 & 887 & 51.9 & -50 & .2285 \\
\hline Female & 884 & 51.4 & 823 & 48.1 & 61 & .1398 \\
\hline White & 1,422 & 82.6 & 1,495 & 87.4 & -73 & .1765 \\
\hline Black & 143 & 8.3 & 129 & 7.5 & 14 & .3958 \\
\hline Other races & 156 & 9.1 & 86 & 5.0 & 70 & .0000 \\
\hline Spanish origin & 95 & 5.5 & 131 & 7.7 & -36 & .0164 \\
\hline Mexican & 68 & 4.0 & 89 & 5.2 & -21 & .0933 \\
\hline \multicolumn{7}{|l|}{$1975-1980^{\mathrm{b}}$} \\
\hline Total & 1,725 & 100.0 & 1,770 & 100.0 & -45 & .4465 \\
\hline Male & 811 & 47.0 & 876 & 49.5 & -65 & .1135 \\
\hline Female & 914 & 53.0 & 894 & 50.5 & 20 & .6381 \\
\hline White & 1,502 & 87.1 & 1,621 & 91.6 & -119 & .0332 \\
\hline Black & 153 & 8.9 & 96 & 5.4 & 57 & .0003 \\
\hline Other races & 71 & 4.1 & 52 & 2.9 & 19 & .0861 \\
\hline Spanish origin & 107 & 6.2 & 146 & 8.2 & -39 & .0140 \\
\hline Mexican & 77 & 4.5 & 107 & 6.0 & -30 & .0267 \\
\hline \multicolumn{7}{|l|}{$1970-1975^{b}$} \\
\hline Total & 1,664 & 100.0 & 1,520 & 100.0 & 144 & .0107 \\
\hline Male & 790 & 47.5 & 784 & 51.6 & 6 & .8798 \\
\hline Female & 874 & 52.5 & 736 & 48.4 & 138 & .0006 \\
\hline White & 1,456 & 87.5 & 1,406 & 92.5 & 50 & .3500 \\
\hline Black & 143 & 8.6 & 70 & 4.6 & 73 & .0000 \\
\hline Other races & 66 & 4.0 & 43 & 2.8 & 23 & .0270 \\
\hline Spanish origin & 118 & 7.1 & 97 & 6.4 & 21 & .1518 \\
\hline Mexican & 79 & 4.7 & 75 & 4.9 & 4 & .7472 \\
\hline
\end{tabular}

aData pertain to migrants over one year of age.

${ }^{b}$ Data pertain to migrants five years old and over.

${ }^{\mathrm{c}}$ Numbers may not sum to totals because of rounding.

${ }^{d}$ The p-value represents the observed significance level, or the level of significance at which one is indifferent between accepting or rejecting the null hypothesis that net migration is zero.

Source: Special tabulations from the March Current Population Survey, prepared by the U.S. Bureau of the Census. Figures for 1975-1980 do not agree with those in Table 7 because the Current Population Survey sample comes from a smaller universe than the decennial census.

this overall movement of population there were conspicuous differences by sex, race, and ethnic groups. Greater numbers of men, whites, and especially Hispanics left California than entered in the late 1970 s and early 1980s. The Hispanic net outflow amounted to 39 thousand persons between 1975 and 1980 , and to another 36 thousand over the next three years. This pattern is particularly noteworthy because it represents a reversal of an earlier trend towards net internal movement of persons of Hispanic origin into California, the largest share of whom came from Texas. Over the en- tire 1970-1983 period, substantially more blacks entered the state than left, maintaining an earlier tendency. Finally, persons of other races, many of whom were Indochinese refugees, also entered California in larger numbers than those leaving between 1970 and 1983.

The family structure of migration to and from California is revealed by the age distribution of migrants shown in Table 9. In-migrants tended to be disproportionately concentrated in the age groups 20-29 and 65 years and over, whereas out-migrants were more heavily repre- 
sented at ages under 20 and between 30 and 64 . Figures on net migration suggest that there was a net outflow from California of families with minor children, but that young adults in their twenties and persons entering retirement continued on balance to find California an attractive place to live.

We also found socioeconomic differences in the migrant flows. Data in Table 10 show that the inflow between 1970 and 1983 was weighted towards more skilled professional and nonprofessional workers, and that the outflow was largely comprised of less skilled workers. In particular, there was an estimated net gain of 205 thousand white-collar workers into California over the 13-year period and an estimated net loss of 134 thousand blue-collar workers to other states. Educational dif- ferences parallel those by occupational status. Persons with some college education who entered California between 1970 and 1983 outnumbered those who left by an estimated 272 thousand. Meanwhile there was a net exodus from the state of approximately 68 thousand persons with an eighth-grade education or less.

In sum, while immigration to California has soared since 1970 , net internal migration to this region has virtually stopped. And it has stopped for the reason that there is a decreasing propensity of people to move to California coupled with a rising tendency to leave for other states. The only net migrants from other parts of the nation are better-educated professional workers, while there has been a net outmigration of unskilled blue-collar and service workers with limited education.

Table 9

Migration Within the United States to and from California, by Age of Migrants: 1970-1983

(numbers in thousands)

\begin{tabular}{|c|c|c|c|c|c|c|}
\hline \multirow{2}{*}{$\begin{array}{l}\text { Period and Age } \\
\text { Group }\end{array}$} & \multicolumn{2}{|c|}{ In-migrants ${ }^{c}$} & \multicolumn{2}{|c|}{ Out-migrants $^{c}$} & \multirow{2}{*}{$\begin{array}{c}\text { Net } \\
\text { migrants }^{c}\end{array}$} & \multirow{2}{*}{$\begin{array}{c}\text { p- } \\
\text { value }^{d}\end{array}$} \\
\hline & Number & Percent & Number & Percent & & \\
\hline \multicolumn{7}{|l|}{$1980-1983^{a}$} \\
\hline Total & 1,721 & 100.0 & 1,710 & 100.0 & 11 & .8510 \\
\hline Under 20 & 463 & 26.9 & 477 & 27.9 & -14 & .6479 \\
\hline $20-29$ & 667 & 38.8 & 592 & 34.6 & 75 & .0345 \\
\hline $30-44$ & 345 & 20.0 & 375 & 21.9 & -30 & .2635 \\
\hline $45-64$ & 165 & 9.6 & 207 & 12.1 & -42 & .0293 \\
\hline 65 and over & 85 & 4.9 & 62 & 3.6 & 23 & .0573 \\
\hline \multicolumn{7}{|l|}{$1975-1980^{b}$} \\
\hline Total & 1,725 & 100.0 & 1,770 & 100.0 & -45 & .4465 \\
\hline Under 20 & 376 & 21.8 & 513 & 29.0 & -137 & .0000 \\
\hline $20-29$ & 636 & 36.9 & 463 & 26.2 & 173 & .0000 \\
\hline $30-44$ & 378 & 21.9 & 464 & 26.2 & -86 & .0030 \\
\hline $45-64$ & 186 & 10.8 & 250 & 14.1 & -64 & .0021 \\
\hline 65 and over & 150 & 8.7 & 79 & 4.5 & 71 & .0000 \\
\hline \multicolumn{7}{|l|}{$1970-1975^{\mathrm{b}}$} \\
\hline Total & 1,664 & 100.0 & 1,520 & 100.0 & 144 & .0107 \\
\hline Under 20 & 487 & 29.3 & 411 & 27.0 & 76 & .0112 \\
\hline 20-29 & 568 & 34.1 & 460 & 30.3 & 108 & .0007 \\
\hline $30-44$ & 363 & 21.8 & 371 & 24.4 & -8 & .7678 \\
\hline $45-64$ & 172 & 10.3 & 214 & 14.1 & -42 & .0324 \\
\hline 65 and over & 74 & 4.4 & 65 & 4.3 & 9 & .4451 \\
\hline
\end{tabular}

"Data pertain to migrants over one year of age.

bData pertain to migrants five years old and over.

'Numbers may not sum to totals because of rounding.

dThe p-value represents the observed significance level, or the level of significance at which one is indifferent between accepting or rejecting the null hypothesis that net migration is zero.

Source: Special tabulations from the March Current Population Survey, prepared by the U.S. Bureau of the Census. Figures for 1975-1980 do not agree with those in Table 7 because the Current Population Survey sample comes from a smaller universe than the decennial census. 
Table 10

Migration Within the United States to and from California, by Education and Occupation: 1970-1983 (numbers in thousands)

\begin{tabular}{|c|c|c|c|c|c|c|}
\hline \multirow{2}{*}{$\begin{array}{l}\text { Period and } \\
\text { Item }\end{array}$} & \multicolumn{2}{|c|}{ In-migrants $f$} & \multicolumn{2}{|c|}{ Out-mirrants $f$} & \multirow{2}{*}{$\begin{array}{l}\text { Net } \\
\text { migrants }\end{array}$} & \multirow{2}{*}{$\begin{array}{c}\text { p- } \\
\text { value }\end{array}$} \\
\hline & Number & Percent & Number & Percent & & \\
\hline \multicolumn{7}{|l|}{$1980-1983^{a}$} \\
\hline \multicolumn{7}{|l|}{ Education } \\
\hline $\begin{array}{l}\text { Persons } 18 \text { years and } \\
\text { older }\end{array}$ & 1,342 & 100.0 & 1,309 & 100.0 & 33 & .5216 \\
\hline 8 years or less & 68 & 5.1 & 75 & 5.7 & -7 & .5582 \\
\hline $9-12$ years & 636 & 47.4 & 619 & 47.3 & 17 & .6313 \\
\hline More than 12 years & 638 & 47.5 & 614 & 46.9 & 24 & .4976 \\
\hline \multicolumn{7}{|l|}{ Occupation } \\
\hline $\begin{array}{l}\text { Persons } 16 \text { years and } \\
\text { older }\end{array}$ & 1,374 & 100.0 & 1,352 & 100.0 & 22 & .6735 \\
\hline White collarc & 472 & 34.4 & 451 & 33.4 & 21 & .4894 \\
\hline $\begin{array}{l}\text { Blue collar and } \\
\text { service workers }\end{array}$ & 268 & 19.5 & 295 & 21.9 & -27 & .2551 \\
\hline $\begin{array}{l}\text { Other } \\
\text { 1975-1980 } \\
\end{array}$ & 633 & 46.1 & 604 & 44.7 & 29 & .4096 \\
\hline \multicolumn{7}{|l|}{ Education } \\
\hline $\begin{array}{l}\text { Persons } 18 \text { years and } \\
\text { older }\end{array}$ & 1,394 & 100.0 & 1,325 & 100.0 & 69 & .1857 \\
\hline 8 years or less & 69 & 4.9 & 112 & 8.5 & -43 & .0013 \\
\hline $9-12$ years & 565 & 40.5 & 606 & 45.7 & -41 & .2308 \\
\hline More than 12 years & 760 & 54.5 & 607 & 45.8 & 153 & .0000 \\
\hline \multicolumn{7}{|l|}{ Occupation } \\
\hline $\begin{array}{l}\text { Persons } 16 \text { years and } \\
\text { older }\end{array}$ & 1,442 & 100.0 & 1,376 & 100.0 & 66 & .2137 \\
\hline White collar ${ }^{c}$ & 587 & 40.7 & 482 & 35.1 & 105 & .0013 \\
\hline $\begin{array}{l}\text { Blue collar and } \\
\text { service workers }\end{array}$ & 292 & 20.2 & 386 & 28.1 & -94 & .0003 \\
\hline $\begin{array}{c}\text { Other }^{\mathrm{e}} \\
1970-1975^{\mathrm{b}} \\
\end{array}$ & 564 & 39.1 & 506 & 36.8 & 58 & .0761 \\
\hline \multicolumn{7}{|l|}{$\overline{\text { Education }}$} \\
\hline $\begin{array}{l}\text { Persons } 18 \text { years and } \\
\text { older }\end{array}$ & 1,240 & 100.0 & 1,149 & 100.0 & 91 & .0626 \\
\hline 8 years or less & 80 & 6.5 & 98 & 8.5 & -18 & .1769 \\
\hline $9-12$ years & 589 & 47.5 & 575 & 50.0 & 14 & .6815 \\
\hline More than 12 years & 571 & 46.0 & 476 & 41.4 & 95 & .0033 \\
\hline \multicolumn{7}{|l|}{ Occupation } \\
\hline $\begin{array}{l}\text { Persons } 16 \text { years and } \\
\text { older }\end{array}$ & 1,291 & 100.0 & 1,195 & 100.0 & 96 & .0541 \\
\hline White collar ${ }^{c}$ & 411 & 31.8 & 332 & 27.8 & 79 & .0037 \\
\hline $\begin{array}{l}\text { Blue collar and } \\
\text { service workers }\end{array}$ & 263 & 20.3 & 276 & 23.1 & -13 & .5755 \\
\hline Other ${ }^{e}$ & 620 & 47.9 & 586 & 49.1 & 34 & .3275 \\
\hline
\end{tabular}

${ }^{\text {a }}$ Data pertain to migrants over one year of age.

bData pertain to migrants five years old and over.

'Includes professional, technical, and kindred workers, managers and administrators, except farm; sales workers; clerical and kindred workers.

dIncludes craft and kindred workers; operatives; laborers, except farm; service workers; and farm workers.

'Includes persons unemployed, in the Armed Forces, and out of the labor force.

f Numbers may not sum to totals because of rounding.

gThe p-value represents the observed significance level, or the level of significance at which one is indifferent between accepting or rejecting the null hypothesis that net migration is zero.

Source: Special tabulations from the March Current Population Survey, prepared by the U.S. Bureau of the Census. Figures for 1975-1980 do not agree with those in Table 7 because the Current Population Survey sample comes from a smaller universe than the decennial census. 
The similarity between the socioeconomic characteristics of net out-migrants from California and those of Mexican immigrants suggests that the flow from Mexico substituted for internal migration. This suggestion is strengthened by net migration estimates for sub-regions of California. No other area of the state was more strongly affected by migration from Mexico between 1970 and 1980 than was Los Angeles County. Our estimates indicate that over the same period, however, Los Angeles lost approximately 372 thousand workers through internal migration to other parts of California and the nation. Conversely, the balance of southern California excluding Los Angeles County, an area that was less influenced by Mexican immigration, gained 360 thousand net workers from other parts of the U.S., including Los Angeles County. ${ }^{3}$

\section{Discussion}

A general picture of the impact of Mexican immigration to Southern California can be synthesized from the analysis presented above. As workers, Mexicans were absorbed into the economy of the region by taking jobs at the lower end of the occupational scale, primarily in manufacturing. While manufacturing jobs showed some increase during the period of rapid immigration, the number of such jobs taken by immigrants exceeded the number formed. Many of these jobs were in the lowwage non-durable goods manufacturing industry, and many may have been created solely by the availability of these low-skill workers. At the same time, unemployment rates in the Los Angeles labor market showed no evidence of adverse effects from immigration. Significantly, black workers who potentially may be the group most seriously affected by a surge of low-wage immigrants, showed a general upgrading in their occupational status. Further investigations are required to establish whether immigration leads to an elevation of native workers in terms of occupation and income.

Large scale immigration to California, and especially to Los Angeles, may have been responsible for a major alteration in the pattern of internal migration in the United States. Although the general pattern of movement to the West continued throughout the 1970s, California experienced a sharp decline in net migration due to a reduction in the rate of in- migration and a rise in the rate of outmigration. The data suggest that there were important differences in the characteristics of these flows. On balance, in-migrants were generally in their early working years and came with high levels of skill and without families, while out-migrants were generally less skilled and moved with their families. Mexican immigrants who came to California in this period were overwhelmingly low-skill workers. They may have served as labor market complements to skilled internal in-migrants and, at the same time, as substitutes for less-skilled workers. In other words, our results suggest a conclusion that the demand in California for low-wage low-skill workers that was once met by internal migration is now being satisfied by immigrants from Mexico. These conclusions are tentative, and further research is needed to establish the dynamics of interaction between immigration and internal migration.

We expect that the forces driving immigration, especially that from Mexico, will intensify and that this immigration will continue to generate pressure for immigration reform. However major changes in immigration legislation must be guided by an understanding of labor market dynamics in areas where immigrants concentrate. Little is known about the level of business dependence that develops around the availability of low-wage workers in the economies of these areas. Since immigrants may actually bolster these economies by providing labor for industries that produce for import substitution, adequate consideration must be given to immigration reforms that could suddenly reduce the number of undocumented workers by return migration, deportation, or legalization.

\section{FOOTNOTES}

\begin{abstract}
'Data on net interregional migration to the West are derived from the decennial censuses of population for $1940,1960,1970$, and 1980.

'The special tabulations reported on here were prepared under the general supervision of Kristin Hansen at the U.S. Bureau of the Census.

${ }^{3}$ These estimates are derived by subtracting the employment growth one would have observed based on natural increase and immigration alone from actual total employment growth between 1970 and 1980 in the affected regions.
\end{abstract}

\section{REFERENCES}

Eldridge, Hope T. and Dorothy S. Thomas. 1964. Demographic Analysis and Interrelations, Population 
Redistribution and Economic Growth: United States 1870-1950, Vol. III. Philadelphia: The American Philosophical Society.

Hamermesh, Daniel S. and James Grant. 1979. Econo. metric Studies of Labor-Labor Substitution and Their Implications for Policy, Journal of Human Resources, 14(Fall): 518-542.

Hernandez, Jose. 1971. Foreign Migration into Californiá. Pp. 61-92 in Kingsley Davis and Frederick G. Styles (eds.), California's Twenty Million, University of California, Berkeley, Institute of International Studies.

Immigration and Naturalization Service. 1981. Statistical Yearbook of the Immigration and Naturalization Service, 1979. Washington, D.C.: U.S. Government Printing Office.

Johnson, George E. 1980. The Labor Market Effects of Immigration. Industrial and Labor Relations Review, (April).

Morrison, Peter A. 1971. The Role of Migration in California's Growth. Pp. 33-60 in Kingsley Davis and Frederick G. Styles (eds.), California's Twenty Million,
University of California, Berkeley, Institute of International Studies.

Muller, Thomas. 1984. The Fourth Wave: California's Newest Immigrants, A Summary. Washington, D.C.: The Urban Institute Press.

North, David S. and Marion F. Houstoun. 1976. The Characteristics and Role of Illegal Aliens in the U.S. Labor Markets: An Exploratory Study. Washington, D.C.: New Trans Century Foundation and Linton and Company, Inc.

Passel, Jeffrey S. and Karen A. Woodrow. 1984. Geographic Distribution of Undocumented Immigrants: Estimates of Undocumented Aliens Counted in the 1980 Census by State, paper presented at the annual meeting of the Population Association of America, Minneapolis, Minnesota, May 3-5.

Piore, Michael J. 1979. Birds of Passage: Migrant Labor and Industrial Societies, New York: Cambridge University Press.

U.S. Bureau of Labor Statistics. Employment and Earnings, selected issues. 